\title{
The Impact of Private Ownership Structure on Risk Taking by Pakistani Banks: An Empirical Study
}

\author{
Muhammad Sajjad Hussain ${ }^{1}$, Dr. Muhammad Muhaizam Bin Musa ${ }^{2}$, \\ Dr. Abdelnaser Omran Ali \\ 1 Ph.D. Candidate, School of Economics, Finance and Banking, College of Business, \\ Universiti Utara Malaysia, Sintok, 06010, Kedah State, Malaysia \\ 2 Senior Lecturer, School of Economics, Finance and Banking, College of Business, \\ Universiti Utara Malaysia, Sintok, 06010, Kedah State, Malaysia \\ ${ }^{3}$ Associate Professor, Faculty of Engineering Sciences, Bright Star University, El-Brega city, \\ Libya \\ Email: sajjadgift@gmail.com
}

\begin{abstract}
The financial crisis of 2007-09 was converted the focus of researchers and regulators toward bank risk-taking and this study is also analyzed the private ownership structure impact on Pakistani bank's risk-taking. This study selects the all Pakistani private banks for investigation and data is collected from financial statements from 2005 to 2016. Most of the past studies found a negative impact of private ownership structure on bank risk-taking and this study is also indicated the negative relationship between private ownership and bank risk-taking. On the other, non-performing loans are double than the international standards that highlighted the owner's attention toward high risky investments for high return. Thus, this study suggests that check this relationship with other factors that forced the owner's behavior toward risk.
\end{abstract}

Keywords: $\quad$ Ownership structure, Risk-taking, Regulations, Banks of Pakistan

\section{Introduction}

The contribution of the financial sector in economic development is increasing with the passage of time. This can force the attention of regulators towards its soundness. The World Bank Report (2017) highlighted the high level of interest of World Bank towards the economic betterment of the world. World Bank's mission statement showed their focus on two major goals, to boost the shared prosperity is the first goal while eliminate the extreme poverty by the end of 2030 is the second goal. The first goal is achieving by raising income growth while the second goal is achieving by minimizing the ratio of people living less than $\$ 1.90$ a day. World Bank is collaborating with public and private partners, civil societies and 
country government for achieving these goals. World Bank also attracting the beneficiaries and stakeholders of every country to ensure that the opportunity is available for everyone to show his or her potential. World Bank's financial assistance also contributes its parts in the economic betterment of the developing countries of the world. This financial assistance playing a crucial role in the economic development of the developing countries.

According to the World Bank Report (2017), reliable and affordable energy power is necessary for the development but every country is not avail this type of facility and World Bank provided the low-carbon option of energy as a solution of this problem. For the solution of energy crisis World Bank also provided the finance facilities such as $\$ 1$ billion to Indian solar projects and $\$ 1.5$ billion to Ukraine, Vietnam and Turkey for small grids. One of the visions of World Bank is "A Water-Secure World for all" and for this vision World Bank mobilized the private capital by giving financial support toward safe water for all. As a result, millions of people of different countries get the access of water sources (World Bank, 2017). Furthermore, digital technology is also essential for every industry in the world for productivity improvement. For the solution of this issue World Bank provided the affordable internet access to more than 4 billion people that they participate in digital economy. Moreover, developing countries are also supported by the World Bank in different ways such as financial assistance is provided for the improvement of private sector infrastructure, transport sector, and protection for natural resources. This contribution of World Bank highlighted its importance in economy betterment and also attracts the attention of regulators to provide the safeguard to this economically important institution of the world.

\section{A. Research Problem}

The credit risk control is the main objective of maintain the Capital Adequacy ratio (CAR) but it is not effective in Pakistani banking industry. Pakistani banks continues tightening the CAR but the situation of non-performing loans or credit risk that getting worse every year since after 2005(SBP, 2017). Moreover, SBP (2016) mentioned the condition of CAR and NPLs in the annual report and expressed their concern regarding increasing level of CAR and NPLs. SBP (2016), reported that NPLs increased from $6.9 \%$ to $12.8 \%$ while capital adequacy requirement is increased from $12.7 \%$ to $17.2 \%$ which shows that CAR is not effective enough to control the risk-taking problem in the banks of Pakistan. Similarly, Hussain, Mosa, and Omran (2017)has also highlighted the increasing level of risk-taking by Pakistani banks in term of NPLs ratio that increased and reached to 12.6 percent from 6.9 
percent while capital adequacy ratio increased and reached to $14.1 \%$ from $8.9 \%$ that unable to control the risk-taking by Pakistani banks.

\section{B. Research Objectives}

The purpose of the study is to determine the relationship of private ownership structure with the risk-taking by the banks of Pakistan. Specific objective of this study is to examine the relationship between the private ownership structure and risk-taking by banks of Pakistan.

\section{Banking Sector of Pakistan: An Overview}

State Bank of Pakistan (SBP) was established in 1948 and its major function is to regulate the whole banking industry of Pakistan. Banking industry of Pakistan consists upon 31 banks, out of them five are government banks, four are under foreign ownership and remaining twenty two are under the private control. The six banks are concentrated the majority of banking industry of Pakistan such as MCB Bank Limited, National Bank Limited (NBL), Allied Bank Limited (ABL), Habib Bank Limited (HBL), Bank Alfalah Limited and United Bank Limited (UBL). These Six banks are the largest competitor as well as hold large stake of Pakistani banks. In addition, these banks make up more than 57 percent deposits and 53 percent advances collectively in the market (Alam, Raza, \& Akram, 2011). Additionally, all the banks that are operating in the country must comply the Basel II minimum capital standards. Unbanked rural population, limited access to technology and religious factor are reasons of huge difference in population (195million) and accounts (43 million) but high speed mobile internet, increase awareness of banking and advent of Islamic banking create the improvement in the growth of banking in Pakistan(Alam et al., 2011). Consequently, the improvement in growth and performance has been observed in the banking sector of Pakistan. Banking industry of Pakistan is improving and growing with the passage of time. According to the State Bank of Pakistan Report (2017), deposits growing and reached to PKR 11,092 billion from PKR 4, 786, total assets increased to PKR 15,134 billion from PKR 6.516 billion and lending rose to PKR 5,025 billion to PKR 3,240 billion from 2009 to 2016. Moreover, State Bank of Pakistan Report (2016) highlighted that Macro-economic conditions are continuously improved during 2016. Furthermore, growing GDP by $4.7 \%$, declining inflation about $2.9 \%$ and stability of exchange rate are the indications of economic improvement in the country. In addition, 7.8 percent growth rate in banking, 100 percent increase in credit provided to the private sector, 100 percent increase in "Net foreign investment" and 5.7 percent increase in "Gross domestic fixed capital investment" are noted during the year 
2016(SBP, 2016). Whereas, regulatory requirements regarding taking risk becoming suffocating for the banking industry. State Bank of Pakistan imposed tough capital requirements in order to avoid extensive risk taking over the past decade.

Furthermore, weak supervision, liquidity issues and high level of non-performing loans are the major factors that are affecting the performance badly(Shafiq \& Nasr, 2010). State Bank forced the banking industry to implement the capital regulations provided by Basel Committee on Banking Supervision (BCBS) to limit the extensive risk-taking activities(Hussain et al., 2012). In addition, State Bank also changes the ownership structure to eliminate the agency issues and avoid the risk situation in the banking industry. But World Bank Report (2016) mentioned that more than adequacy ratio maintained by the banks and changing ownership structure is not effective enough to control over the risk-taking of the banks because the non-performing loans (NPLs) increases from $6.9 \%$ to $12.4 \%$ from 20062015. These figures highlighted the non-effectiveness of changing ownership structure and capital adequacy ratio in order to control over the risk-taking of Pakistani banks.

Increasing level of non-performing Loans (NPLs) ratio of Pakistani banks since 2006 to 2015 are presented in Table 1.

Table 1: Non-performing Loans \& Capital Adequacy Ratio of Pakistan's Banks

\begin{tabular}{|c|c|c|c|}
\hline Years & $\begin{array}{c}\text { Non-performing Loans / } \\
\text { Total Loans (\%) }\end{array}$ & Years & $\begin{array}{c}\text { Non-performing Loans / } \\
\text { Total Loans (\%) }\end{array}$ \\
\hline $2005-2006$ & 6.9 & $2006-2007$ & 7.6 \\
\hline $2007-2008$ & 10.5 & $2008-2009$ & 12.6 \\
\hline $2009-2010$ & 14.9 & $2010-2011$ & 15.3 \\
\hline $2011-2012$ & 15.9 & $2012-2013$ & 14.8 \\
\hline $2013-2014$ & 12.8 & $2014-2015$ & 12.4 \\
\hline
\end{tabular}

\section{Literature Review}

This study is going to check the relationship between bank risk-taking and private ownership structure and related past studies are discussed below:

\section{A. Bank Risk Taking}

Risk is the exposure to danger for the banks and, in addition, banks and risk are high correlated with each other while risk-taking is the willingness of owners to take risk (Buch, Eickmeier, \& Prieto, 2014). Liquidity and risk-taking are tightly interconnected, additionally; external funding and transferability constraints are declining due to high risk tolerance. Consequently, risk-taking is supported by these weaken constraints that allow the banks to engage in projects containing extensive risk for high return (Borio \& Zhu, 2012). 
Pakistan Journal of Humanities and Social Sciences, 6(3), 2018

Furthermore, Jiménez, Lopez, and Saurina (2013), analyzed the Spanish banks and concluded that extensive risk-taking affected the bank's stability. High level of competition situations are existing in the market that required high profit motivation that leads towards excessive risk-taking that become a cause of instability. Moreover, Bolton, Mehran, and Shapiro (2015), examined in their study that high risk-taking affected the creditors, taxpayers, depositors and financial system as a whole. In addition, in case of high risk-taking situation, if the returns are not according to the expectations then that risk-taking can badly affect to the performance of the banks. Similarly, deposit insurance and high deposits goals decreases the discipline of the market that leads the banks towards excessive risk-taking(Khan, Scheule, \& Wu, 2017). Profit maximization goals of the shareholders required to move towards excessive risk-taking and this situation creates instability situation in the banks (Mollah, Hassan, Al Farooque, \& Mobarek, 2017). Entire financial system were suffered due to the latest financial crisis 200708 and the major cause of these crisis was only the excessive risk-taking(Paligorova \& Santos, 2017). Likewise, Ashraf (2017), indicated that the origin of crisis was the United State because of excessive risk-taking situation was existed in US banking environment due to high profit motives, attraction of stakeholders and high competition in the market. Additionally, Ehrlich and Radulescu (2017), analyzed the banks of United Kingdom and investigated that one of the major factor of recent financial crisis was extensive risk-taking of the bank.

\section{B. Private Ownership Structure}

Private ownership structure refers to the major share are held by individuals, banks, and institutions that are under private control. Fewer agency issues have been observed in private ownership due to the continuous interaction between managers and owners that inline the goals of managers and owners and reduces the agency issues. Insider ownership, family ownership, and institutional ownership are the part of private ownership (Akhtar \& Hanif, 2010). Moreover, Claessens, Djankov, and Lang (2000), analyzed the corporate sector of East Asian countries and found that lack of agency issue situation has been observed in family ownership. The family members of the managers and shareholder held some share and inline their goals with family members that reduce the agency issues in the institution. Furthermore, According to the Ackert and Athanassakos (2003); Ishak and Napier (2004) and Khanna and Yafeh (2007), diversified portfolio investment exist in institutional ownership. Similarly, Lepetit, Nys, Rous, and Tarazi (2008), examined the Europeans banks and concluded that institutional ownership prefer the improvement and changes in governance and also prefer 
changes in the risk-taking behavior of the institutions. Furthermore, Dong, Meng, Firth, and Hou (2014), investigated the Chinese commercial banks and indicated that the experience of institutional ownership of managing the cost and controlling the other shareholders are very high that restricted the institution in the less risky environment. Similarly, $\mathrm{Li}$, Song, and $\mathrm{Wu}$ (2015) and Alzoubi (2016), mentioned in their study that insider ownership also has the expertise, resources, and power to monitor the investment and shareholders to control them from excessive risk-taking. Moreover, insider ownership is very keen observer about the risky investment and have the greater expertise to take reason risk(Cheng, Cummins, \& Lin, 2017). Furthermore, Wang and Shailer (2018), indicated that superior the private ownership than state ownership with respect to their performance. All of the previous studies mentioned that private ownership is relatively less risky than other types of ownership but this situation is not exist in the Pakistani environment because major banking system is under private ownership and still risk environment exist in the market as mentioned in Table (1) increasing level of non-performing loans in the banks of Pakistan.

\section{Private Ownership Structure and Bank Risk Taking}

Private ownership structure has a negative impact on the risk due to the less political interference, fewer agency issues and strong supervision (Akhtar \& Hanif, 2010). Likewise, Laeven and Levine (2009), indicated that institutional ownership has a significant negative impact on the risk-taking because this ownership has greater experience about the investment that it generates more profits by taking the minimum risk. However, Paligorova (2010), found a positive relationship between institutional ownership and risk taking because of profit maximization goals of the corporate sector of 38 countries. Whereas, Srivastav and Hagendorff (2016), found that there is the risk-averse behavior of insider ownership has been observed and also pursuing the strategies of risk reduction. Similarly, Zhong (2017), analyzed the Chinese banking system and found that lack of agency issues reduces the chances of failure in private ownership structure of the banks. Moreover, Dong, Girardone, and Kuo (2017), conducted the study on Chinese banks and examined that bank risk-taking increases when up to 5 percent shares held by insiders and decreases bank risk-taking when up to 25 percent or more shares held by insiders. Additionally, Zheng, Huq, Rahman, and Ashraf (2017), analyzed the banks of developing countries and examined the significant negative impact of insider ownership on bank risk-taking. Likewise, Samet, Boubakri, and Boubaker (2018), found that private-ownership is less risky than other ownership of the institutions. 


\section{Research Structural and Hypotheses Development}

A number of previous studies showed that private ownership structure has a negative impact on the bank risk taking. Based on these previous studies, it was hypothesized that:

H1: There is a negative relationship between private ownership structure and risk-taking by the Pakistani Banks.

Bank risk-taking used as depend variable in the study and proxied by Z-SCORE and calculated by this formula $\mathrm{Z}-\mathrm{SCORE}=(\mathrm{ROA}+\mathrm{CAP}) / \mathrm{S}$ while private ownership structure used as predictor in the study and proxied and calculated by Total number of shares held private owners in period " $\mathrm{t}$ "/ Total no of shares held in period " $\mathrm{t}$ " (Azureen, 2012). Variables are mentioned in the framework in Figure (1) given below:

Figure 1: Conceptual Framework of the study

Independent Variable

Private Ownership Structure

\section{Research Methods}

This study is carried on all the private commercial banks of Pakistan from the year 2005-2016. Two types of banks are existing in the country, conventional and Islamic. Islamic banks are very limited in the country (only five) and also different in nature, therefore, eliminated from the analysis. Thus, conventional banks are selected for the analysis in this study. Furthermore, conventional banks have also several kinds such as commercial, investment and micro-finance banks. This study selects the private commercial banks because it represents biggest part in the banking sector of the country. There are fifteen private commercial banks are currently operating in the country. The data were collected from all the private commercial bank's financial statements for the year 2005 to 2016 and total observation is 180 ( $15 \mathrm{x}$ 12). Table (2) shows all types of private commercial banks selected in the study. 
Table 2: Private Commercial Banks of Pakistan

\begin{tabular}{|l|l|l|}
\hline United Bank Limited & Habib Metropolitan Bank & Bank Alfalah Limited \\
\hline Allied Bank Limited & Faisal Bank & NIB Bank \\
\hline Muslim Commercial Bank & Askari Bank & Soneri Bank \\
\hline Habib Bank Limited & Standard Chartered Bank & Summit Bank \\
\hline Bank Al Habib & JS Bank & Samba Bank \\
\hline
\end{tabular}

Source: State Bank of Pakistan (2016)

\section{Results and Discussions}

After collection the data from above-mentioned banks, statistical analysis is run on the data. This analysis includes descriptive statistical analysis such as mean, standard deviation, minimum, maximum values, and correlation while inferential statistics analysis includes regression analysis. Table (3) showed the descriptive statistics used in the study. The dependent variable is Z-score while independent variable is private ownership structure. There are 180 (15 Banks x 12 years) observations in the study and mentioned in the table. The mean of z-score is 8.977 and Private ownership (PVTOWN) is .7356 while the standard deviation of Z-score 4.8797 and PVTOWN is .2693.The minimum value of Z-score is 1.24 while maximum value is 30.04 and on the other hand, the minimum value of PVTOWN is 0 and the maximum value is .999. Pearson Correlation of PVTOWN with z-score is less than 1 which is only -0.0006 .

Table 3: Descriptive Analysis of Variables

\begin{tabular}{|c|c|c|c|c|c|c|}
\hline Variables & Obs. & Mean & Std. Deviation & Min. & Max. & Correlation \\
\hline Z-score & 180 & 8.977 & 4.8797 & 1.24 & 30.04 & 1 \\
\hline PVTOWN & 180 & 0.7356 & 0.2693 & 0 & 0.999 & -0.0006 \\
\hline
\end{tabular}

\section{A. Hausman Test}

Random effect model (RAM) and fixed effect model (FEM) are the two prominent panel model are being used in this study by selecting the suitable one through Hausman test (Gujarati \& Porter, 2003). If the null hypothesis is accepted then random effect model is appropriate and vice versa. The result of Hausman test of this study is Prob. $=0.0001$ which is less than 5 percent which means reject the null hypothesis that means fixed effect model is suitable for the study.

\section{B. Fixed Effect Model (FEM)}

"Fixed effects model takes into account the "individuality" of each cross-sectional unit. It lets the intercept to vary for each firm but still assume that the slope coefficients are constant across firms". The estimation of fixed effects model is as follows: 
The general regression estimation:

$$
\text { Yit }=\beta 1 \mathrm{i}+\beta 2 \mathrm{X} 2 \mathrm{it}+\mu \mathrm{it}
$$

Where

$\mathrm{i}=i$ th cross-sectional unit

$\mathrm{t}=t$ th time period

$\mathrm{i}=$ intercept term

Table 4 presents the fixed effect regression that shows the overall probability value which is 0.0000 less than 5 percent which means the model is a good fit. Similarly, the probability values of PVTOWN are 0.0000 less than 5 percent which means the significant relationship between PVTOWN and Z-SCORE. The results of the study is similar with Chou and Lin (2011) and Barry, Lepetit, and Tarazi (2011) because the coefficient value of PVTOWN is -10.46 which indicates the negative relationship between the variables and if there is 1 percent increase in the independent variable, the dependent variable will decrease 10.46 percent and vice versa.

\section{Table 4: Fixed Effect Model}

\begin{tabular}{|l|l|l|l|l|l|l|}
\hline Z-score & Coef. & Std. Error. & t & \multicolumn{2}{|l|}{ P>|z| } & \multicolumn{2}{|c|}{ 95\% Conf. Interval) } \\
\hline PVTOWN & -10.46 & 2.106 & -4.96 & 0.000 & -14.615 & -6.297 \\
\hline Cons & 16.67 & 1.575 & 10.58 & 0.000 & 13.559 & 19.781 \\
\hline Prob $>$ chi2 $=0.0000$ &
\end{tabular}

\section{Conclusion and Recommendations}

Regulators continually changes the regulations such as Basel II converted into Basel III and also changes and tighten the ownership structures with respect to risk-taking. Banks of Pakistan also follow the regulation and tighten the ownership structure in terms of risk-taking. Most of the banking sector of Pakistan is under private control and consider strong enough to take the risk. Most of the factor forces the owners to take a risk such as high-profit motive, competition and loan growth. This study found a negative relationship between private ownership structure and bank risk-taking as previous studies findings. This resultshows that ownership structure is experienced enough in terms of risk taking but Table (1) above mentioned shows that non-performing loans are double than the international standards. It means other factors are existing in the market that forces the owners to invest in risky assets to generate more profits. Thus, this study recommended to the regulators that they should put extra attention on the owner's decisions about investment and its associated risk. This study also recommended to the policymakers that they put restrictions on high risky decisions of the 
investors. Moreover, this study provides the fututre direction to the researchers that they check this relationship by using the other factors such as competition, profitability and loan growth as a mediator or moderator. 
Pakistan Journal of Humanities and Social Sciences, 6(3), 2018

\section{References}

Ackert, L. F., \& Athanassakos, G. (2003). A Simultaneous Equations Analysis of Analysts' Forecast Bias, Analyst Following, and Institutional Ownership. Journal of Business Finance \& Accounting, 30(7-8), 1017-1042.

Akhtar, \& Hanif, M. (2010). X-Efficiency Analysis of Pakistani Commercial Banks. International Management Review, 6(1), 12-25.

Alam, H. M., Raza, A., \& Akram, M. (2011). A financial performance comparison of public vs private banks: The case of commercial banking sector of Pakistan. International Journal of Business and Social Science, 2(11), 54-65.

Alzoubi, S. S. E. (2016). Ownership Structure and Earnings Management: Evidence from Jordan. International Journal of Accounting \& Information Management, 24(2), 135161.

Ashraf, B. N. (2017). Political institutions and bank risk-taking behavior. Journal of Financial Stability, 29, 13-35.

Azureen, N. A. R. (2012). The Impact of Ownership Structure, Moral Hazard and Capital Regulation on Risk Taking in Malaysian Banks. Universiti Utara Malaysia.

Barry, T. A., Lepetit, L., \& Tarazi, A. (2011). Ownership Structure and Risk in Publicly Held and Privately Owned Banks. Journal of Banking \& Finance, 35(5), 1327-1340.

Bolton, P., Mehran, H., \& Shapiro, J. (2015). Executive compensation and risk taking. Review of Finance, 19(6), 2139-2181.

Borio, C., \& Zhu, H. (2012). Capital regulation, risk-taking and monetary policy: a missing link in the transmission mechanism? Journal of Financial Stability, 8(4), 236-251.

Buch, C. M., Eickmeier, S., \& Prieto, E. (2014). In search for yield? Survey-based evidence on bank risk taking. Journal of Economic Dynamics and Control, 43, 12-30.

Cheng, J., Cummins, J. D., \& Lin, T. (2017). Organizational Form, Ownership Structure, and CEO Turnover: Evidence From the Property-Casualty Insurance Industry. Journal of Risk and Insurance, 84(1), 95-126.

Chou, S., \& Lin, F. (2011). Bank's Risk-Taking and Ownership Structure-Evidence for Economics in Transition Stage. Applied Economics, 43(12), 1551-1564.

Claessens, S., Djankov, S., \& Lang, L. H. (2000). The Separation of Ownership and Control in East Asian Corporations. Journal of Financial Economics, 58(1), 81-112.

Dong, Y., Girardone, C., \& Kuo, J.-M. (2017). Governance, efficiency and risk taking in Chinese banking. The British Accounting Review, 49(2), 211-229. 
Dong, Y., Meng, C., Firth, M., \& Hou, W. (2014). Ownership structure and risk-taking: Comparative evidence from private and state-controlled banks in China. International Review of Financial Analysis, 36, 120-130.

Ehrlich, M., \& Radulescu, D. (2017). The taxation of bonuses and its effect on executive compensation and risk-taking: Evidence from the UK experience. Journal of Economics \& Management Strategy, 26(3), 712-731.

Gujarati, D. N., \& Porter, D. C. (2003). Basic Econometrics. 4th: New York: McGraw-Hill.

Hussain, M. S., Mosa, M. M., \& Omran, A. (2017). The Mediating Impact of Profitability on Capital Requirement and Risk Taking By Pakistani Banks. Journal of Academic Research in Economics, 9(3).

Hussain, M. S., Ramzan, M., Ghauri, M. S. K., Akhtar, W., Naeem, W., \& Ahmad, K. (2012). Challenges and failure of Implementation of Basel Accord II and reasons to adopt Basel III both in Islamic and Conventional Banks. International Journal of Business and Social Research, 2(4), 149-174.

Ishak, Z., \& Napier, C. (2004). Corporate ultimate ownership and corporate diversification in Malaysia. Paper presented at the Fourth Asia Pacific Interdisciplinary Research in Accounting Conference.

Jiménez, G., Lopez, J. A., \& Saurina, J. (2013). How does competition affect bank risktaking? Journal of Financial Stability, 9(2), 185-195.

Khan, M. S., Scheule, H., \& Wu, E. (2017). Funding liquidity and bank risk taking. Journal of Banking \& Finance, 82, 203-216.

Khanna, T., \& Yafeh, Y. (2007). Business groups in emerging markets: Paragons or parasites? Journal of Economic literature, 45(2), 331-372.

Laeven, L., \& Levine, R. (2009). Bank governance, regulation and risk taking. Journal of Financial Economics, 93(2), 259-275.

Lepetit, L., Nys, E., Rous, P., \& Tarazi, A. (2008). Bank income structure and risk: An empirical analysis of European banks. Journal of Banking \& Finance, 32(8), 14521467.

Li, S., Song, X., \& Wu, H. (2015). Political connection, ownership structure, and corporate philanthropy in China: A strategic-political perspective. Journal of Business Ethics, 129(2), 399-411. 
Pakistan Journal of Humanities and Social Sciences, 6(3), 2018

Mollah, S., Hassan, M. K., Al Farooque, O., \& Mobarek, A. (2017). The governance, risktaking, and performance of Islamic banks. Journal of Financial Services Research, 51(2), 195-219.

Paligorova, T. (2010). Corporate risk taking and ownership structure: Working Paper Financial Markets Department Bank of Canada.

Paligorova, T., \& Santos, J. A. (2017). Monetary policy and bank risk-taking: Evidence from the corporate loan market. Journal of Financial Intermediation, 30, 35-49.

Samet, A., Boubakri, N., \& Boubaker, S. (2018). Does public-private status affect bank risk taking? Worldwide evidence. Journal of International Financial Markets, Institutions and Money, 1-41.

SBP. (2016). State Bank of Pakistan annual performance review FY2015-16. Karachi, Pakistan.

SBP. (2017). State Bank of Pakistan annual performance review FY2016-17. Karachi, Pakistan.

Shafiq, A., \& Nasr, M. (2010). Risk management practices followed by the commercial banks in Pakistan. International Review of Business Research Papers, 6(2), 308-325.

Srivastav, A., \& Hagendorff, J. (2016). Corporate Governance and Bank Risk-taking. Corporate Governance: An International Review, 24(3), 334-345.

Wang, K. T., \& Shailer, G. (2018). Does Ownership Identity Matter? A Meta-analysis of Research on Firm Financial Performance in Relation to Government versus Private Ownership. Abacus, 54(1), 1-35.

WorldBank. (2016). Annual Report 2016 Washington, D.C., United States.

WorldBank. (2017). Annual Report 2017. Washington, D.C., United States.

Zheng, C., Huq, M.-U. S., Rahman, M. M., \& Ashraf, B. N. (2017). The Effects of Ownership Structure on Banks' Capital and Risk-taking Behavior: Empirical Evidence from Developing Country. Research in International Business and Finance, 4(2), 15-27.

Zhong, H. (2017). Commercial Bank Ownership Structure and Risk Preference. Journal of Mathematical Finance, 7(02), 437-450. 